\title{
Effect of red chicory extract on scopolamine-induced memory impairment in mice
}

\author{
So Won Yun, Seung Yeon Baek, Mee Ree Kim* \\ Department of Food and Nutrition, Chungnam National University, Daejeon 34134, Korea
}

\section{Scopolamine으로 유도한 기억력 저하 마우스에 대한 적치커리 추출물의 개선효과}

\author{
윤소원 · 백승연 · 김미리* \\ 충남대학교 식품영양학과
}

\begin{abstract}
We investigated the protective effects and mechanisms of red chicory extract (RCE) on scopolamine-induced memory impairment in mice. Antioxidant effects were investigated by measuring DPPH radical scavenging activity, and cell viability and intracellular ROS levels were examined by inducing cytotoxicity with L-glutamate in HT-22 cells. In addition, mice were administered orally with RCE $(150$ and $300 \mathrm{mg} / \mathrm{kg})$. Memory was evaluated using Morris water maze (MWZ) and passive avoidance tests. Administration of SRCE $150 \mathrm{~kg} / \mathrm{mg}$ significantly increased escape latency time $(\mathbf{p}<\mathbf{0 . 0 5})$ that was shortened by scopolamine. It further increased platform crossing numbers after 7 days of training in MWZ tests $(\mathbf{p}<0.05)$, which were significantly shortened by scopolamine, and prolonged latency $(\mathbf{p}<0.01)$ in passive avoidance tests. Biochemical findings showed significantly increased total glutathione (GSH) (p<0.05), glutathione S-transferase (GST) $(p<0.01)$, and glutathione peroxidase (GPx) $(\mathbf{p}<0.01)$ in the mice administered RCE $150 \mathrm{mg} / \mathrm{kg}$ compared with the scopolamine-induced positive control. Glutathione reductase (GR) did not significantly differ between the RCE $300 \mathrm{mg} / \mathrm{kg}$ and scopolamine-induced groups $(p<0.05)$. These results suggested that RCE has antioxidant activity and enhances scopolamine-induced cognitive impairment by attenuating oxidative stress.
\end{abstract}

Key words : red chicory, scopolamine, morris water maze test, antioxidant enzyme

\section{Introduction}

Red chicory (Cichorium intybus L.) has received attention for containing phytochemicals, such as phenolic acids, $\mathrm{fl}$ avonoids, and anthocyanins, which are beneficial to health (Bais and Ravishankar, 2001). The high anthocyanin content in red chicory, making red chicory leaves red, accounted for $50-55 \%$ of the total phenolic compounds and show high antioxidant activity (Francesca et al., 2020).
In vivo, polyphenols prevent the production of reactive oxygen species (ROS), which is related to the initiation and progression of many pathological processes (Diplock, 1998; Elstner, 1991). In addition, phenolic compounds in leafy vegetables exert antioxidant activity, protecting against peroxyl radicals generated by lipid peroxidation (Rossetto et al., 2005).

Alzheimer's disease (AD) is a typical brain disease. Worldwide, the number of dementia patients in 2015 was 50

\footnotetext{
*Corresponding author. E-mail : mrkim@cnu.ac.kr, Phone :+82-42-821-6837, Fax : +82-42-821-8671

Received 26 May 2020; Revised 20 July 2020; Accepted 25 August 2020.

Copyright (c) The Korean Society of Food Preservation.

This is an Open Access article distributed under the terms of the Creative Commons Attribution Non-Commercial License (http://creativecommons.org/licenses/by-nc/4.0) which permits unrestricted non-commercial use, distribution, and reproduction in any medium, provided the original work is properly cited.
} 
million, and this number is expected to more than triple by 2050 (Alzheimer's Association, 2016). AD may shorten the life expectancy of elderly people and cause serious public problems and economic burden (Alzheimer's Association, 2016).

Reactive oxygen species (ROS), which are generated during diverse metabolic activity in the body, also contribute to the pathophysiology of brain neurological diseases such as $\mathrm{AD}$ (Froelich and Riederer, 1995). In a previously reported study, the cerebrospinal fluid of Alzheimer's patients showed oxidative damage from the formation of oxidative and nitrate proteins, lipid peroxides, and DNA fragments and a collapse of the antioxidant defense system (Martin et al., 2019). In the collapsed antioxidant defense system, the levels of glutathione (GSH), an antioxidant enzyme in the brain, were decreased (Saharan and Mandal, 2014). Additionally, glutathione S-transferase (GST), which is one of the main antioxidant enzymes maintaining the antioxidant defense system and regulating GSH, leads to cellular detoxification and inhibits the activation of signals in cellular apoptosis (Raza, 2011).

Scopolamine increases the activity of acetylcholinesterase, which breaks down acetylcholine in the cholinergic nervous system, decreasing memory ability for a short time (Bartus, 2000). In this regard, scopolamine has been widely used to examine the effect of memory improvement in short-term memory loss-induced animal studies (Ebert and Kirch, 1998). In the scopolamine-induced memory impairment model, the increase in free radicals aggravated the generation of lipid peroxidation related to malondialdehyde and damaged the cellular antioxidant enzymes, including catalase, glutathione peroxidase (GPx), and glutathione reductase (GR), and altered superoxide dismutase (SOD) (Tang, 2019).

Therefore, in this study, we investigated whether red chicory extracted with methanol or ethyl acetate possessed antioxidant activity and whether the antioxidant effect of red chicory extract could improve cognitive dysfunction and behavioral deficits in scopolamine-induced memory-impaired mice.

\section{Materials and methods}

\section{Preparation of red chicory extracts (RCE)}

Red chicory (593 g) was obtained from S\&D Inc. (Yeon- gi, Korea). Dried red chicory (52 g) was extracted at room temperature in a sonicator (Power Sonic 420, Hwashin Co., Seoul, Korea) for one day with $80 \%$ methanol $(1 \mathrm{~L})$. The mixture was filtered through No.3 filter paper (Whatman International Limited, Kent, UK) three times and concentrated to dryness (Evaporator, MG-2100, Buchi, Switzerland). The $80 \%$ methanol extract $(40 \mathrm{~g})$ was dissolved in distilled water. The water and fractionate solution was fractionated in a separatory funnel with an equivalent amount of ethyl acetate and the extracted of ethyl acetate was separated and evaporated. The ethyl acetate extraction (yield $3 \mathrm{~g}$ ) was used in the present study.

\section{Animals}

Six-week-old male ICR mice were purchased from Raon Bio Company (Daejeon, Korea). The mice were raised at constant temperature $\left(24.0 \pm 2.0^{\circ} \mathrm{C}\right)$ and humidity $(55 \pm 10 \%)$ with a $12 \mathrm{~h}: 12 \mathrm{~h}$ light/dark cycle in an animal house with free access to chow (Purina, Cheongju, Korea) and water. The mice were weighed once a week. The animal experiments were conducted in compliance with the Guide for the Care and Use of Laboratory Animals of the National Institutes of Health (Registration No: CNU-00549).

\section{Treatments}

After a one-week adjustment period, the mice were randomly divided into five groups $(6$ mice/group) and treated. The procedures are shown in Table 1. Briefly, $2 \mathrm{mg}$ per kg of scopolamine (scopolamine hydrobromide, Sigma Chemical Co., St. Louis, MO, USA) dissolved in saline was injected intravenously (i.v) daily for four weeks. Red

Table 1. Experimental design

\begin{tabular}{cc}
\hline Group & Treatment \\
\hline CON & Saline (i,v) + saline (orally) \\
SCO & Scopolamine $2 \mathrm{mg} / \mathrm{kg}(\mathrm{i} . \mathrm{v})+$ saline (orally) \\
TAC & $\begin{array}{c}\text { Scopolamine } 2 \mathrm{mg} / \mathrm{kg} \text { (i.v) }+ \\
\text { tacrine } 10 \mathrm{mg} / \mathrm{kg} \text { (orally) }\end{array}$ \\
SRCE 150 & $\begin{array}{c}\text { Scopolamine } 2 \mathrm{mg} / \mathrm{kg} \text { (i.v) }+ \\
\text { RCE }\end{array}$ \\
& Scopolamine $2 \mathrm{mg} / \mathrm{kg}$ (orally) \\
RCE (i.v) $300 \mathrm{mg} / \mathrm{kg}$ (orally)
\end{tabular}

${ }^{1)} \mathrm{RCE}$, red chiocry extraction. 
chicory or tacrine (9-amino-1,2,3,4-tetrahydroacridine hydrochloride hydrate, Sigma Chemical Co.) dissolved in saline was given by oral gavage daily $30 \mathrm{~min}$ after scopolamine injection for three weeks. Tacrine is used as an inhibitor of scopolamine (Baek et al., 2020). In the 4th week, red chicory or tacrine was given by oral gavage $1 \mathrm{~h}$ before the water maze task and the passive avoidance test. Then, scopolamine was injected $30 \mathrm{~min}$ before the water maze task and the passive avoidance test.

\section{HT-22 cell cultures and treatment}

This experiment were selected according to our preliminary experiment (Baek and Kim, 2020). Mouse hippocampus derived cell, HT-22 cells, were maintained in Dulbecco's modified Eagle's medium (DMEM) with 10\% fetal bovine serum (FBS), 100 units $/ \mathrm{mL}$ penicillin and 100 $\mu \mathrm{g} / \mathrm{mL}$ streptomycin at $37^{\circ} \mathrm{C}$ with $5 \% \mathrm{CO}_{2}$.

\section{WST assay for cell viability}

Cell viability was assessed using the EZ-Cytox Cell viability Kit (Daeil Lab, Seoul, Korea) according to the manufacturer's instructions. HT-22 cells were plated into 96-well plates at a density of $3 \times 10^{3}$ cells/well for $24 \mathrm{~h}$, with each well containing $100 \mu \mathrm{L}$ of medium. The cells were treated with $5 \mathrm{mM}$ glutamate. After $11 \mathrm{~h}$ of incubation, 10 $\mu \mathrm{L}$ of the EZ-Cytox solution was added to each well, and the plates were incubated at $37^{\circ} \mathrm{C}$ for $2 \mathrm{~h}$. The absorbance was read with an Emax Precision Microplate Reader (Molecular Devices, Sunnyvale, CA, USA) at $450 \mathrm{~nm}$. The percentage of surviving cells was determined relative to the control group.

\section{Intracellular ROS level assay}

The level of intracellular reactive oxygen species (ROS) was measured using 2',7'-dichlorofluorescein diacetate (DCFDA) (Invitrogen, CA, USA) as described previously. Twelve hours after glutamate treatment, the cells were stained with $10 \mu \mathrm{M}$ DCFDA in Hanks' balanced salt solution (HBSS) for $30 \mathrm{~min}$ in the dark, and the fluorescence was monitored using a microplate reader (Beckman Coulter DTX 880 Multimode Detector, Brea, CA, USA) at an excitation wavelength of $485 \mathrm{~nm}$ and an emission wavelength of $525 \mathrm{~nm}$. Finally, the measured value were calculated and marked as \% of control group.

\section{DPPH radical scavenging activity}

Radical scavenging ability was determined by adding 300 $\mu \mathrm{L}$ of $1.5 \times 10^{-4} \mathrm{mM}$ DPPH solution to $900 \mu \mathrm{L}$ of sample with different concentrations of red chicory $(10,5,2.5,1.25$, $0.625,0.3125,0.125$, and $0.0625 \mathrm{mg} / \mathrm{mL})$. The reacted solution were placed in the dark at room temperature and after $30 \mathrm{~min}$, the $\mathrm{OD}$ value was measured at $515 \mathrm{~nm}$. The blank contained $300 \mu \mathrm{L}$ of methanol and $900 \mu \mathrm{L}$ of DPPH solution. Vitamin C was used as a positive control. DPPH radical scavenging activity was determined by the following equation:

$$
\begin{aligned}
& \text { DPPH radical scavenging activity }(\%)=\frac{A_{c}-A_{s}}{A_{c}} \times 100 \\
& A_{C}: 900 \mu \mathrm{L} 1.5 \times 10^{-4} \mathrm{mM} \mathrm{DPPH}+300 \mu \mathrm{L} \mathrm{MeOH} . \\
& \mathrm{A}_{\mathrm{S}}: 900 \mu \mathrm{L} 1.5 \times 10^{-4} \mathrm{mM} \mathrm{DPPH}+300 \mu \mathrm{L} \text { sample in } \\
& \text { different concentrations }
\end{aligned}
$$

\section{Morris water maze test}

The Morris water maze (MWM) test was conducted for seven consecutive days before the end of the experiment. RCE or tacrine was given by oral gavage $1 \mathrm{~h}$ before, then scopolamine at $2 \mathrm{mg} / \mathrm{kg}$ body weight was injected $30 \mathrm{~min}$ before the water maze task.

The MWM test for mice consisted of a circular pool with an escape platform with a diameter of $10 \mathrm{~cm}$ installed in a water tank with a width of $60 \mathrm{~cm}$ and a depth of $150 \mathrm{~cm}$. The water tank was divided into quartiles and the escape platform was located in one quartile. The mice were placed anywhere in the remaining quartiles. On the first day of the test, no escape platform was set up and the mice swam freely for two min, then cognitive adaptation training was conducted using the escape platform in different quadrants every trial day. When the animal reached the escape platform, it was allowed to stay on the escape platform for $10 \mathrm{sec}$, and if the escape platform was not found within 120 $\mathrm{sec}$, the mouse was placed on the escape platform for 10 sec to remember the escape platform. On the fifth day of the experiment, the escape platform was removed to measure the working memory, and the latency time for visiting the escape platform was recorded.

\section{Passive avoidance test}

Nocturnal animals have a habit of going from a bright 
place to a dark place. Utilizing this behavior, when a mouse entered a dark room, it was given an electric shock. Finally, the animal equated an electric shock with a dark room through training. Using a partition, the animals were placed in a box divided into two compartments and an electric shock of $0.5 \mathrm{~mA}$ was applied to the stainless grid floor for $5 \mathrm{sec}$ immediately after the animals moved to the dark compartment. The time from the entrance to the illuminated compartment was measured. To confirm the effect of the sample on the long-term memory of the animal, we measured the time it took to enter the dark compartment when placed again in the bright area after $24 \mathrm{~h}$. After each experiment was completed, the box was wiped clean with $70 \%$ alcohol to erase the traces of the immediately preceding experimental animal and not affect the following experiments.

\section{Biochemical analysis}

The animals were euthanized, brain tissue was homogenized with a tissue homogenizer (Hoverlabs, Haryana, India) in a buffer solution (12.5 mM sodium phosphate buffer, $\mathrm{pH} 7.0$, and $400 \mathrm{mM} \mathrm{NaCl}$ ), centrifuged at 1,000 rpm at $4^{\circ} \mathrm{C}$ for $10 \mathrm{~min}$, and the supernatant was collected. The supernatant was stored at $-70^{\circ} \mathrm{C}$ until use.

The levels of total GSH were determined by mixing with $0.1 \mathrm{M}$ potassium phosphate buffer, $10 \mathrm{mM}$ DTNB, and 5 $\mathrm{mM}$ NADPH, equilibrated for $1 \mathrm{~min}$ by adding 1 unit of $\mathrm{GR}$, and the absorbance was measured at $412 \mathrm{~nm}$ using a spectrophotometer. GSH $(0-0.04 \mathrm{mM})$ was used for the standard curve.

GST activity was measured as described previously using 1-chloro 2,4-dinitrobenzene as the substrate (Habig et al., 1974). The standard assay mixture contained $1 \mathrm{mM}$ 1-chloro 2,4-dinitrobenzene (CDNB), $1 \mathrm{mM}$ reduced GSH, and 100 $\mathrm{mM}$ potassium phosphate buffer $(\mathrm{pH} 6.5)$ in a volume of 1 $\mathrm{mL}$. The reaction was followed at $340 \mathrm{~nm}$.

GPx activity was measured by reacting with $0.1 \mathrm{M}$ sodium phosphate butter, $5 \mathrm{mM}$ NADPH, $100 \mathrm{mM}$ GSH, and 1 unit of GR. Three minutes later, $100 \mathrm{mM}$ cumene-OOH was added. Absorbance was measured at 340 $\mathrm{nm}$ with a spectrophotometer.

GR activity was measured in a reaction mixture containing $0.1 \mathrm{M}$ phosphate buffer, $1 \mathrm{M} \mathrm{GSSG}$, and $5 \mathrm{mM}$ $\mathrm{NADPH}$, and the absorbance was measured with a spectrophotometer at $340 \mathrm{~nm}$.

\section{Statistical analysis}

All results are expressed as means \pm SEM. Statistical analyses were performed using IBM SPSS 24 software (Statistical Package for Social Science. SPSS Inc., Chicago IL, USA). Differences between the groups were compared by one-way ANOVA followed by the least significant difference (LSD) test to further analyze the differences between the two groups. A p-value of $<0.05$ was used to indicate statistical significance.

\section{Results and discussion}

\section{Cytotoxicity of RCE on cell viability}

HT-22 cells were exposed to glutamate $(5 \mathrm{mM})$ for 12 $\mathrm{h}$ with or without RCE. As shown in Fig. 1, cell viability was remarkedly reduced by about $50 \%(\mathrm{p}<0.001)$ in the glutamate-only treated group compared to the control group. Treatment with RCE dose-dependently increased cell viability. In the group treated with RCE $100 \mu \mathrm{g} / \mathrm{mL}$, cell viability was the same as the control group. These results showed that RCE exerted a neuroprotective effect against glutamateinduced oxidative stress in HT-22 cells. An extract possessing a high antioxidant effect showed cell protective activity against cell death in HT-22 cells by reducing glutamate-induced oxidative stress (Baek and Kim, 2020).

\section{Effect of RCE on ROS}

To confirm the effect of RCE on the level of ROS, a marker of oxidative stress, The HT-22 cells were exposed

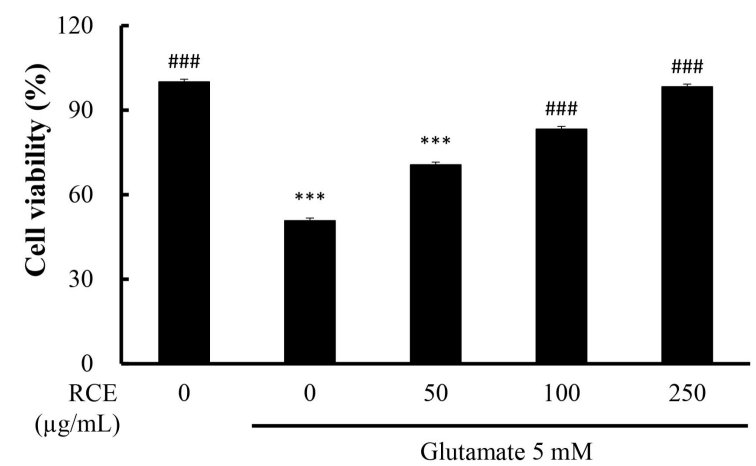

Fig. 1. Effect of RCE on cytoprotectionof glutamate-induced cell death. 
to glutamate, and measured by adding DCFDA reagents. When DCFDA of non-fluorescent DCF, which represents ROS generation. As shown in Fig. 2, treatment with $5 \mathrm{mM}$ glutamate significantly increased ROS production 3-fold compared to the untreated control group. ROS generation in the RCE -treated group was reduced in a dose-dependent manner. Also, ROS production by treatment with 100 to 250 $\mu \mathrm{g} / \mathrm{mL}$ of RCE was effectively reduced to the level of the control group $(\mathrm{p}<0.001)$.

Studies have shown that abundant polyphenols can prevent and treat neurodegenerative diseases. Mulberry fruit extract (Shin et al., 2019) showed a nerve cell protective effect against oxidative stress in HT-22 cells.

\section{Effect of RCE on DPPH scavenging activity}

Substances that react with ROS are considered antioxidants, so are considered radical scavengers (Seyed et al., 2012). DPPH scavenging analysis was used to demonstrate the antioxidant capacity of RCE, and the results are shown in Fig. 3. The $\mathrm{IC}_{50}$ value, which is the concentration at which the radical scavenging activity is $50 \%$, was calculated and obtained (Blois, 1958). The $\mathrm{IC}_{50}$ value of RCE was 37.9 $\mathrm{mg} / \mathrm{mL}$ compared to an $\mathrm{IC}_{50}$ in the vitamin $\mathrm{C}$ positive control of $0.03 \mathrm{mg} / \mathrm{mL}$.

\section{Morris water maze test}

Mice in the scopolamine-treated group showed memory impairment, with a prolonged latency time during seven days of training. Scopolamine-treatment did not decrease the escape latency time to locate the platform in the water maze test. Many dementia model experiments that caused memory damage with scopolamine confirmed that long-term memory

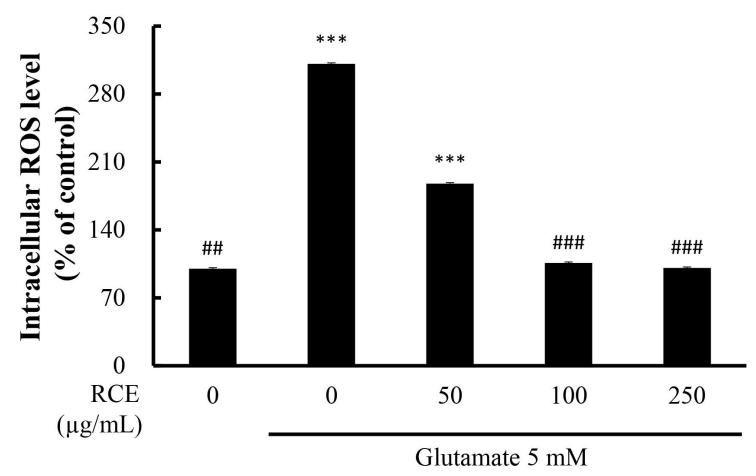

Fig. 2. Effect of RCE on glutamate-induced ROS generation.

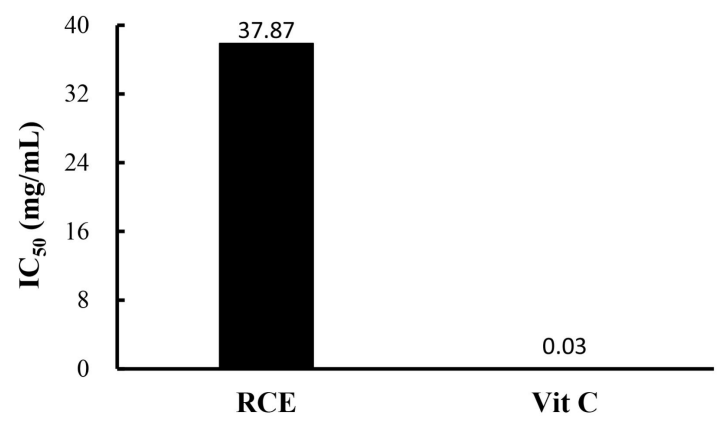

Fig. 3. DPPH scavenging activity of RCE $50 \%$ inhibition concentration (IC50).

damage was induced normally (Rispoli et al., 2004; Lu et al., 2007). Mice treated with scopolamine and RCE showed significantly decreased latency time (Fig. 4A). As shown in Fig. 4B, mice treated with RCE showed significant memory enhancement with decreased escape latency time compared to the scopolamine-alone group. The escape latency time was decreased dose-dependently by treatment with RCE. In addition, the platform crossing numbers in the SRCE 300 group were significantly increased than those treated with tacrine as well as the scopolamine group (Fig. 4C). Through animal behavior experiments, we confirmed the effect of RCE on memory impairment.

\section{Passive avoidance test}

The passive avoidance task was also carried out to determine the effect of RCE on scopolamine-induced memory impairment. As shown in Fig. 5, the scopolaminetreated group showed a significant decrease in latency time compared to the negative control group. Both the tacrine-treated and SRCE 150 groups showed significant memory enhancement by longer latency time compared to the scopolamine-only treated group. Therefore, this result suggests that RCE had a protective effect on scopolamineinduced cognitive impairment.

\section{Effect of RCE on the antioxidant activity in brain tissue}

Glutamate is an excitatory neurotransmitter that regulates the growth and migration of neurons, which play a critical role in learning and memory formation. High concentrations of glutamate reduce the amount of glutathione in the cell by inhibiting cysteine in the cell membrane through the 

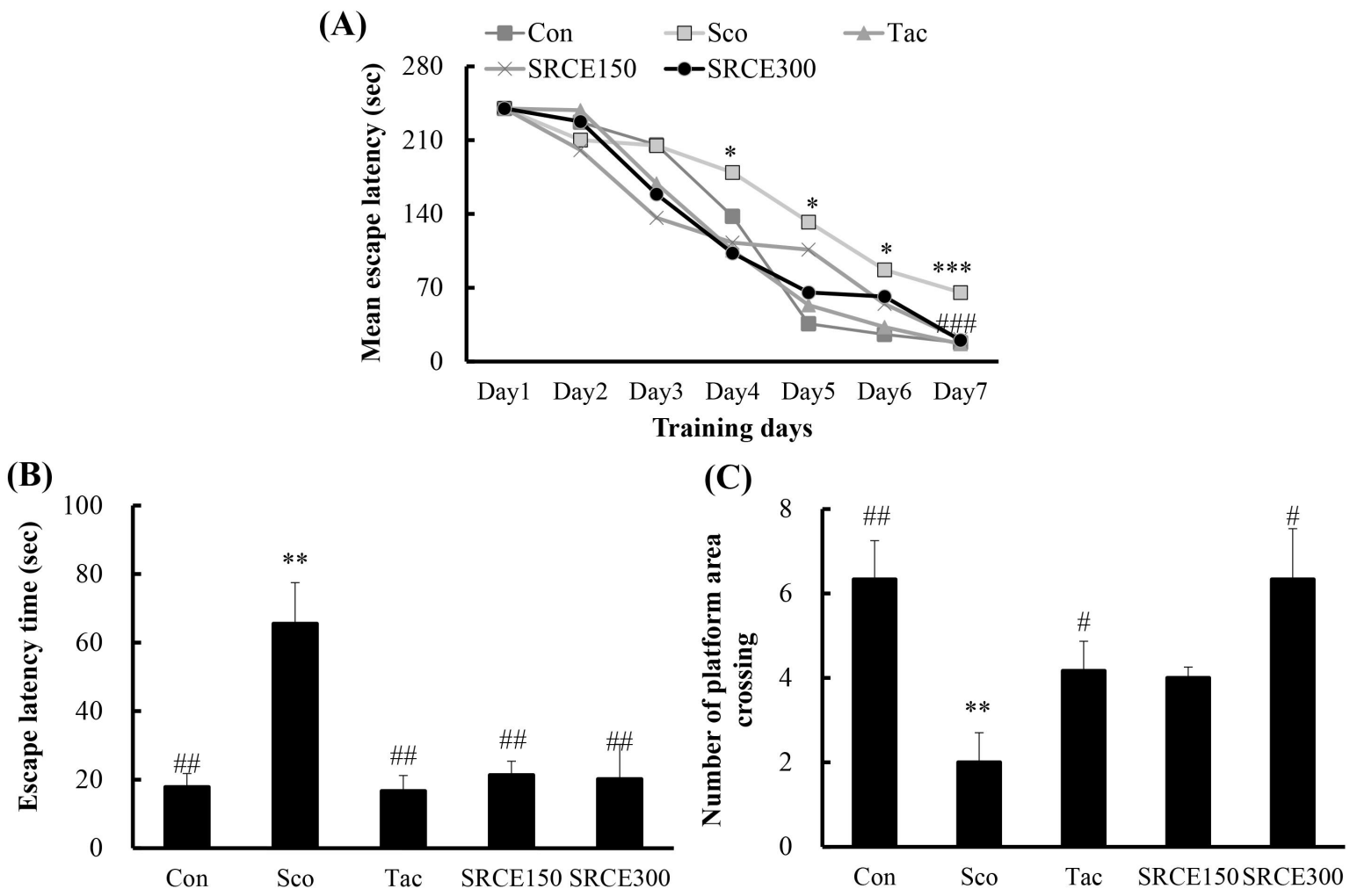

Fig. 4. Effect of RCE on latency time during the training trial sessions (A), on the swimming time (B), and platform crossing times (C) during the probe trial session of the morriswater maze task.

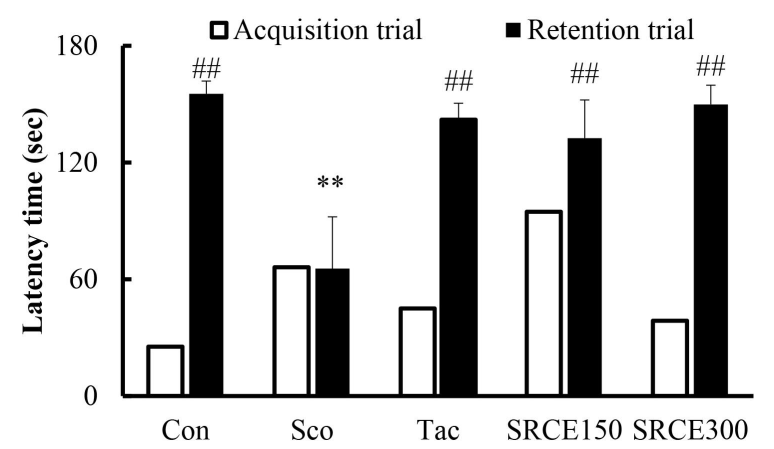

Fig. 5. Effect of RCE on latency time of passive avoidance test.

cystine/glutamate transport system (Fukui et al, 2009). In addition, it increases the production of calcium ions $\left(\mathrm{Ca}^{2+}\right)$ and ROS in cells, causing oxidative stress.

This study measured GSH, GST, GPx, and GR activity to evaluate the effects of RCE. As shown in Fig. 6A, decreased GSH levels were seen in the scopolamine-only treated group, and GSH in the SRCE 150 group was increased to levels in the control group. In addition, the level in the SRCE 300 group was significantly increased over that in the control group. Also, the level of GST in both the SRCE 150 and SRCE 300 groups showed increased activity compared to tacrine group (Fig. 6B).

RCE treatment showed the largest difference in GPx levels compared to the other antioxidant enzymes. The results showed that both the SRCE 150 and SRCE 300 groups had activity twice as high as that of the controls (Fig. 6C).

However, the GR results were slightly different than those of the previous indicators. The SRCE 300 group was significantly different from the scopolamine group but showed lower activity than the control and tacrine groups (Fig. 6D). RCE treatment showed the largest difference in GPx levels compared to the other antioxidant enzymes. The results showed that both the SRCE 150 and SRCE 300 groups had activity twice that of the controls (Fig. 6C).

\section{요 약}

본 연구는 항산화 효과가 뛰어난 적치커리 추출물을 이용 
(A)

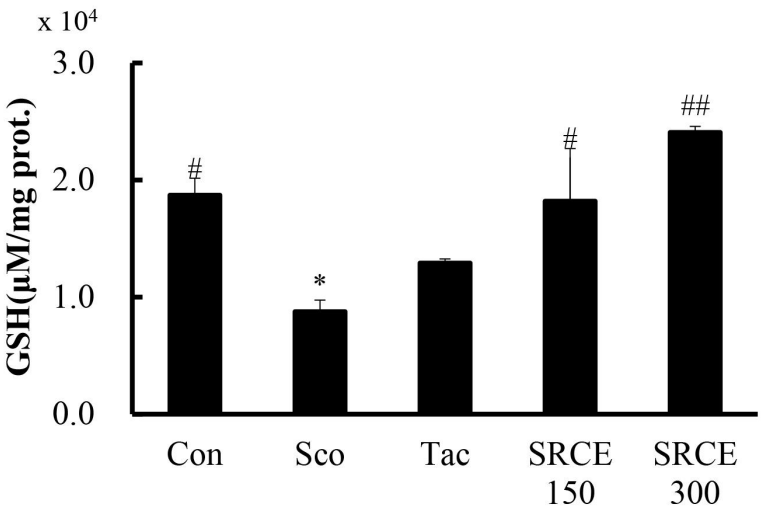

(C)

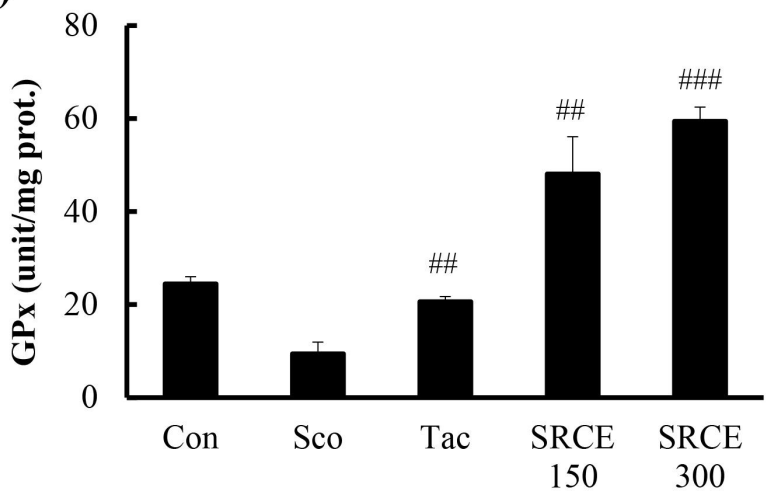

(B)
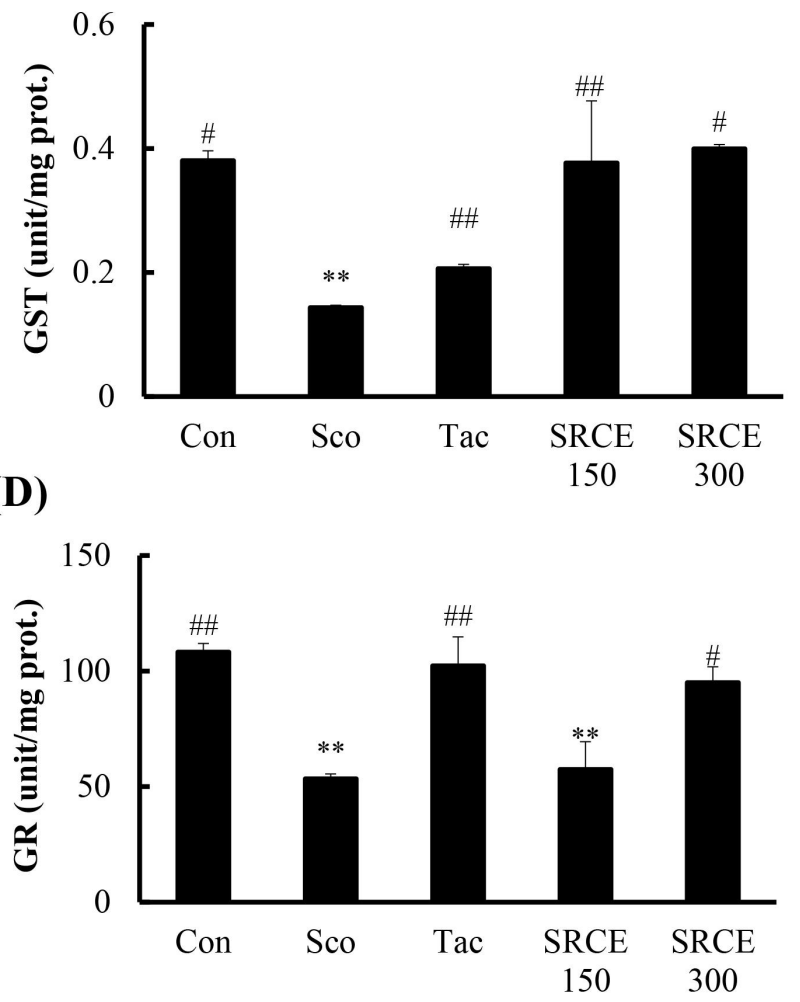

Fig. 6. Antioxidant effect of RCE on the brain tissue of scopolamine-induced memory impaired mice.

Total glutathione (GSH) (A), glutathione S-transferase (GST) (B), glutathione peroxidase (GPx) activity (C) and glutathione reductase (GR) activity (D).

하여, scopolamine으로 유도된 치매 동물모델에서의 인지능 효과를 확인하였다. 항산화 효과를 조사하기 위해 DPPH 라 디칼 소거를 수행하였고, HT-22 세포에서 L-glutamate 로 세 포 독성을 유도함으로써 세포 생존율 및 $\mathrm{ROS}$ 를 조사하였다. 그 결과, 세포 생존율이 농도 의존적으로 증가하였으며, 세포 내 ROS 생성량 또한 정상세포만큼 감소한 것을 알 수 있었 다. 그리고 인지능 개선의 효과를 알아보기 위하여 scopolamine으로 치매를 유도시킨 후, 적치커리 추출물을 150 $\mathrm{mg} / \mathrm{kg}, 300 \mathrm{mg} / \mathrm{kg}$ 을 동일한 시각에 각각 투여하였다. Morris water maze test에서 적치커리 추출물 $(150 \mathrm{mg} / \mathrm{kg} \mathrm{b.w})$ 처리 군에서 scopolamine에 의한 기억 손상이 개선되어 대조군의 escape latency 수준으로 회복되었다. 적치커리 추출물은 통 계적으로 유의성 있게 latency time이 증가하였다. 마지막으 로 적치커리 추출물을 투여한 마우스의 뇌조직 생화학분석 결과를 보면 GR 농도는 적치커리 추출물 $300 \mathrm{mg} / \mathrm{kg}$ 를 투여 군에서 유의적으로 증가하였다. GSH와 GST는 적치커리 추 출물 $150 \mathrm{mg} / \mathrm{kg}$ 투여군의 활성수준이 정상 수준으로 증가하 였으며, 농도 의존적으로 증가하는 것을 볼 수 있었다. 특히 $\mathrm{GPx}$ 는 적치커리 $150 \mathrm{mg} / \mathrm{kg}$ 대조군에 비해 2배 이상의 높은
활성이 나타났다. 이상의 결과로 보았을 때, 적치커리 추출 물은 신경 보호 효과와 scopolamine으로 유도된 치매 동물 모델에서 기억력 개선 및 인지능력을 향상시킬 수 있다고 생 각된다.

\section{Conflict of interests}

The authors declare no potential conflict of interest.

\section{ORCID}

So Won Yun https://orcid.org/0000-0002-6919-9586

Mee Ree Kim https://orcid.org/0000-0003-3813-1447

\section{References}

Alzheimer's Association. 2016 Alzheimer's disease facts and figures. Alzheimers Dement, 12, 459-509 (2016)

Baek SY, Kim MR. Neuroprotective effect of carotenoid-rich 
Enteromorpha prolifera extract via TrkB/Akt pathway against oxidative stress in hippocampal neuronal cells. Mar Drugs, 18, 372 (2020)

Baek SY, Li FY, Kim DH, Kim SJ, Kim MR. Enteromorpha prolifera extract improves memory in scopolamine-treated mice via downregulating amyloid- $\beta$ expression and upregulating BDNF/TrkB Pathway. Antioxidants, 9, 620 (2020)

Bais HP, Ravishankar GA. Cicorium intybus L-cultivation, processing, utility, value addition and biotechnology, with an emphasis on current status and future prospects. J Sci Food Agric, 81, 467-484 (2001)

Bartus RT. On neurodegenerative diseases, models, and treatment strategies: Lessons learned and lessons forgotten a generation following the cholinergic hypothesis. Exp Neurol, 163, 495-529 (2000)

Blois MS. Antioxidant determinations by the use of a stable free radical. Nature, 181, 1199-1200 (1958)

Diplock AT, Charleux JL, Crozier-Willi G, Kok FJ, RiceEvans C, Roberfroid M, Sthal W, Vina-Ribes J. Functional food science and defense against reactive oxidative species. Br J Nutr, 80, 77-112 (1998)

Ebert U, Kirch W. Scopolamine model of dementia: Electroencephalogram findings and cognitive performance. Eur J Clin Invest, 28, 944-949 (1998)

Elstner EF. Oxygen radicals-Biochemical basis for their efficacy. Klin Wochenschr, 69, 949-956 (1991)

Froelich L, Riederer P. Free Radical mechanisms in dementia of Alzheimer type and the potential for antioxidative treatment. Arzneim-Fosch, 45, 443-446 (1995)

Fukui M, Song JH, Choi J, Choi HJ, Zhu BT. Mechanism of glutamate-induced neurotoxicity in HT-22 mouse hippocampal cells. Eur J Pharmacol, 617, 1-11 (2009)

Habig WH, Pabst MJ, Jakoby WB. Glutathione S-transferases. The first enzymatic step in mercapturic acid formation. J Biol Chem, 249, 7130-7139 (1974)

Heimler D, Isolani L, Vignolini P, Tombelli S, Romani A. Polyphenol content and antioxidant activity in some species of freshly consumed salads. J Agric Food Chem, 55, 1724-1729 (2007)

Lu MC, Hsieh MT, Wu CR, Cheng HY, Hsieh CC, Lin YT, Peng W. Ameliorating effect of emodin, a constitute of
Polygonatum multiflorum, on cycloheximide-induced impairment of memory consolidation in rats. J Ethnopharmacol, 112, 552-556 (2007)

Nabavi SM, Nabavi SF, Ebrahimzadeh MA. Free radical scavenging and antioxidant activities of Dorema aitchisonii. J Food Drug Anal, 20, 34-40 (2012)

Raza H. Dual localization of glutathione S-transferase in the cytosol and mitochondria: Implications in oxidative stress, toxicity and disease. The FEBS J, 278, 4243-4251 (2011)

Rispoli V, Rotrioti D, Carelli V, Liberatore F, Scipione L, Marra R, Giorgioni G, Stefano AD. Choline pivaloyl esters improve in rats cognitive and memory performances impaired by scopolamine treatment or the lesions of the nucleus basalis of Meynert. Neurosci Lett, 356, 199-202 (2004)

Rossetto M, Lante A, Vanzani P, Spettoli P, Scarpa M, Rigo A. Red chicories as potent scavengers of highly reactive radicals: A study on their phenolic composition and peroxyl radical trapping capacity and efficiency. J Agric Food Chem, 53, 8169-8175 (2005)

Saharan S, Mandal PK. The emerging role of glutathione in Alzheimer's disease. J Alzheimer's Dis, 40, 519-529 (2014)

Shin SK, Yoo JM, Li, FY, Baek SY, Kim MR. Mulberry fruit improves memory in scopolamine-treated mice: Role of cholinergic function, antioxidant system, and TrkB/Akt signaling. Nutr Neurosci, 1-11 (2019)

Tang KS. The cellular and molecular processes associated with scopolamine-induced memory deficit: A model of Alzheimer's biomarkers. Life Sci, 233, 116695 (2019)

Valis M, Herman D, Vanova N, Masopust J, Vysata O, Hort J, Pavelek Z, Klimova B, Kuca K, Misik J, Karasova JZ. The concentration of memantine in the cerebrospinal fluid of Alzheimer's disease patients and its consequence to oxidative stress biomarkers. Front Pharmacol, 10, 943 (2019)

Zanoni F, Primiterra M, Angeli N, Zoccatelli G. Microencapsulation by spray-drying of polyphenols extracted from red chicory and red cabbage: Effects on stability and color properties. Food Chem, 307, 125535 (2020) 